\title{
Moderate Islamic Education and Religious Digital Literature: The Making of Children's Moderate Identities Through the NU Kids Application
}

\author{
Yusmicha Ulya Afif ${ }^{1}$, Arik Dwijayanto ${ }^{2}$ \\ Institut Agama Islam Negeri Ponorogo, Jl. Pramuka No.156, Po Box 116 Ponorogo $^{1}$, Institut \\ Agama Islam Sunan Giri Ponorogo, Jl. Batong Katong No. 32, Ponorogo ${ }^{2}$ \\ \{yusmicha@iainponorogo.ac.id ${ }^{1}$, muharrik@insuriponorogo.ac.id ${ }^{2}$ \}
}

\begin{abstract}
This article argues that the emergence of digital literature in androidbased applications such as NU Kids is a response to the contestation and fragmentation of religious authority in Indonesia as well as a medium to spread moderate Islam for children and an effort to build alternative religious authority and as a source for the formation of children's moderate identities. Through creative content, NU Kids provides education in the form of encyclopedias and fun games for children to get to know the history and practices of Nahdlatul Ulama. This article aims to explore the latest developments in moderate Islamic narratives in digital religious literature, especially in the segmentation of children. The results of this study indicate that the NU Kids application can be an alternative religious digital literature and a source of moderate religious identity formation for children.
\end{abstract}

Keywords: Moderate Islam; Digital Literature; Children's Identity; NU Kids

\section{Introduction}

The results of a survey conducted by the Center for Islamic and Community Studies (PPIM) of the State Islamic University (UIN) Jakarta regarding religious attitudes in schools (PPIM, 2017) found that there are three main factors that influence a person's religious attitude. The three factors are the teaching provided by their religious teacher or mentor, sources of religious knowledge on the internet, and the government's performance over the past three years. In addition, easy internet access is now also a factor that can connect anyone, including school institutions, to information with negative contents, one of which is radicalism, the internet tends to be more intolerant. Internet access also influences students' understanding of religion, especially access towards social media and the internet among students reached $85 \%$ (PPIM, 2017).

The data shows the fact that sources of religious knowledge in online media have a significant effect in shaping religious understanding for students or children. Especially since the Covid pandemic in mid-March, it has further strengthened online-based learning activities so that the tradition of learning the Quran together at mosques or madrasah diniyah is abandoned and the most possible access as an alternative is to use religious digital literature. 
The presence of religious digital literature is an alternative for parents today who want to teach their children to be religious in a modern and practical way. A child does not need to leave the house to study religion. They can learn at any time according to the time and what knowledge they want. (Azak, 2013). The emergence of Islamic digital literature in Indonesia is a form of alternative media response to the development of millennial da'wah; at the same time this allows it to become an alternative to religious authority. In the old religious authority, kiai / ustaz and classical religious sources played a central role in religious knowledge. Meanwhile, now, the presence of Islamic digital literature is starting to shape the role of the source of religious teachings. This alternative religious authority implicitly guides children to be moderate and have social piety in the digital era. (Lyansari, 2019).

This study analyzes one of the religious digital literature in an android-based application, namely NU Kids as a medium for spreading moderate Islamic values to children and efforts to build alternative religious authority. Through creative content, NU Kids, which was released on August 3 2018, provides education in the form of encyclopedias and fun games for children to get to know the history, figures and religious traditions of Nahdlatul Ulama. The presence of the NU Kids application, which has been downloaded by more than 50 thousand users, is an alternative religious digital literature and a source for the making of moderate children's religious identities in Indonesia.

\section{Research Method}

This study uses a qualitative method. Data was obtained by accessing the NU Kids application available on the Google Play Store. The sampling technique used simple random sampling. From the entire digital religious literature specifically for children on the Google Play Store, researchers decided to choose the NU Kids application as a representation of moderate religious digital literature for children. The content of the NU Kids application contains moderate Islamic values, namely an introduction to the history of Islam in Indonesia, religious figures who contributed to the spread of Islam, local cultural wisdom, struggle songs and educational games. Researchers try to see the value and educational messages in the content with a focus on understanding and analyzing both the visual appearance and the text.

\section{Research Results and Discussion}

\subsection{Learning Religious Moderation by Virtual}

The presence of Islamic digital literature for children is an interesting and important phenomenon to study when online learning activities become the only dominating option during a pandemic. Islamic digital literature is a source of religious knowledge for children, especially for those who live in urban areas. Children can learn religion virtually by accessing Islamic digital literature. By utilizing Islamic digital literature, learning religion for children is more fun. When viewed from its appearance, Islamic digital literature for children consists of two elements. First, illustration elements, used as imagination on the context of the topic being discussed. Illustrations in Islamic digital literature show various forms of animation or cartoons that attract children to learn. Second, the text element is used to convey the meaning of the message in the illustration. Both complement each other in order to achieve learning 
goals, provide understanding to children about religious values. So that it is not only in the form of text as in conventional classical literature. (Lyansari, 2019).

Islamic children's digital literature is a form of visual research (visual studies and visual culture). Visual research in this research is a manifestation of image studies. There are relationship issues that can be observed in visual research, including: space and the purpose of making the visualization itself. So far, visual research has studied objects such as images, illustrations, icons, comics and videos or films (Emmison et al., 2012).

According to William (2015), religion needs to be examined in the visual aspect because religion is a system of symbols so that there is evidence related to religious behavior with icons to represent religious experience from scripture (Morgan, 2005). In addition, the prominent character of postmodern literature is the ideology embedded in the text. Text is presented with a strategy and narrative of values and attitudes naturally, including children's literature (Allan, 2012). Along with the development of technology, the visual religious experience has also undergone digital and print developments. One example of this development is the presence of digital literature for Islamic children.

By displaying images and texts that are packaged creatively, children are interested in accessing Islamic digital literature as in the front page display of the NU Kids application which provides a visual image of a smiling child wearing a white green striped shirt with a sarong and kopyah while carrying a book is a symbol of moderation. Comparing the phenomenon of the Islamization of Berbie in Indonesia has occurred in 2005. Barbie is no longer wearing skimpy clothes, but using veil (hijab) and niqab. This shows that there is a business the formation of religious identity in children. (Budiyanto, 2009).

The front page display of NU Kids shows the religious identity of a child with the Nahdlatul Ulama attribute with a cheerful smile in carrying out religious activities. This gives a message at the beginning to children that The presence of NU Kids application is a representation of moderation symbols which shows the resilience of eastern culture to the culture that comes from the outside, including Islamization of Barbie. (Meneley, 2007).

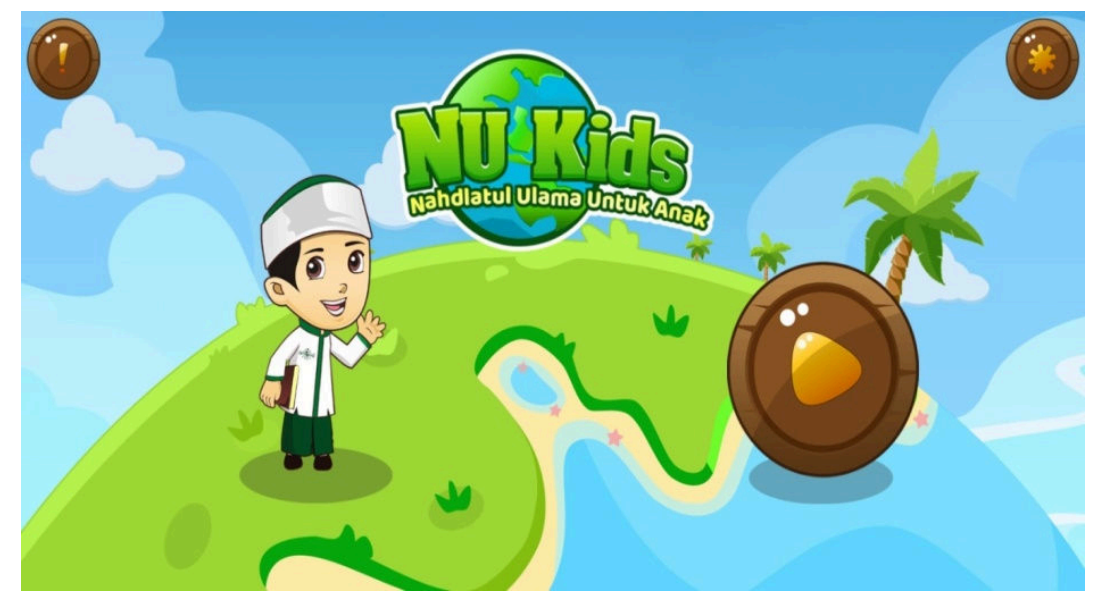

Fig.1. The front Page Display in the NU Kids Application

The menu display in the NU Kids application, which is designed simple and elegant with simple features, presents three different options that can be accessed according to the preferences of today's children, namely Mini Games, Encyclopedias and Songs (Mars). The mini games feature contains educational games with moderate religious values. Likewise with 
the encyclopedia feature which contains the history of the entry of Islam in Indonesia and the ulama figures involved in the spread of Islamic da'wah. The song feature contains a collection of songs (Mars) Nahdlatul Ulama such as Syubbanul Wathan, Mars IPNU, Mars IPPNU, Mars GP Ansor, Mars Banser, Mars PMII, Mars Fatayat, Mars Muslimat and others. These three features are specifically designed for the segmentation of early childhood to elementary school age. Thus, children are encouraged to learn religion in a fun way.

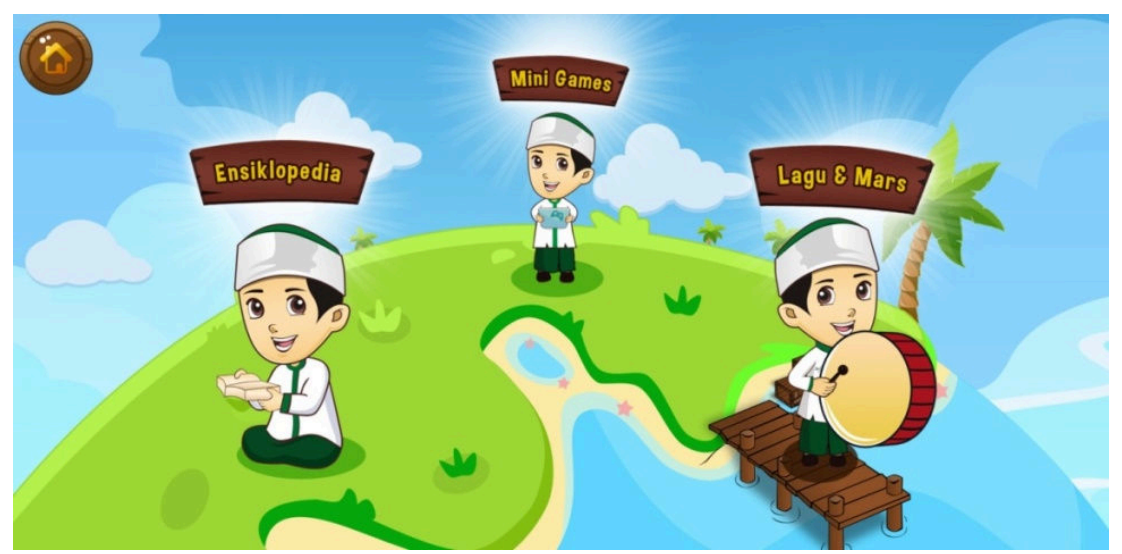

Fig.2. Menu Display in the NU Kids Application

Therefore the presence of Islamic children's digital literature such as NU Kids denotes an attempt to form a moderate generation and have present and future social piety. Children's literature is influenced by subjectivity in term of identity politics. Subjectivity dominates the literature children represented in the text do not deny the existence agency level of each individual to make decisions or attitude (Stephens, 2013).

\subsection{Learning Religious Moderation through the Walisongo Story}

On the Encyclopedia menu, there are three reading options that children can choose from, namely history, figures and culture. In the history menu in the encyclopedia, children will see in the form of flashback illustrations of the history of the ulama who spread Islam in Indonesia, known as "Walisongo". In this historical encyclopedia series, children will be introduced to the roles and struggles of the ulama (Walisongo) who spread Islam in Indonesia. This history is important for children to gain an understanding that the entry of Islam to Indonesia was spread by ulama in a peaceful way without violence. If the literature they read about the arrival of Islam in Indonesia by means of violence through war, it indirectly instills the seeds of radicalism, not moderatism. (Dwijayanto, 2019). The understanding of moderatism in children can be instilled with a historical approach through the story of Walisongo's struggle in spreading Islam in the archipelago. Through the history of Walisongo, children learn about how Walisongo spread Islam by approaching local cultural wisdom such as Wayang, Slametan and other traditions. This then can form an understanding for children to be moderate when the tradition is still being carried out in the environment where they live. 


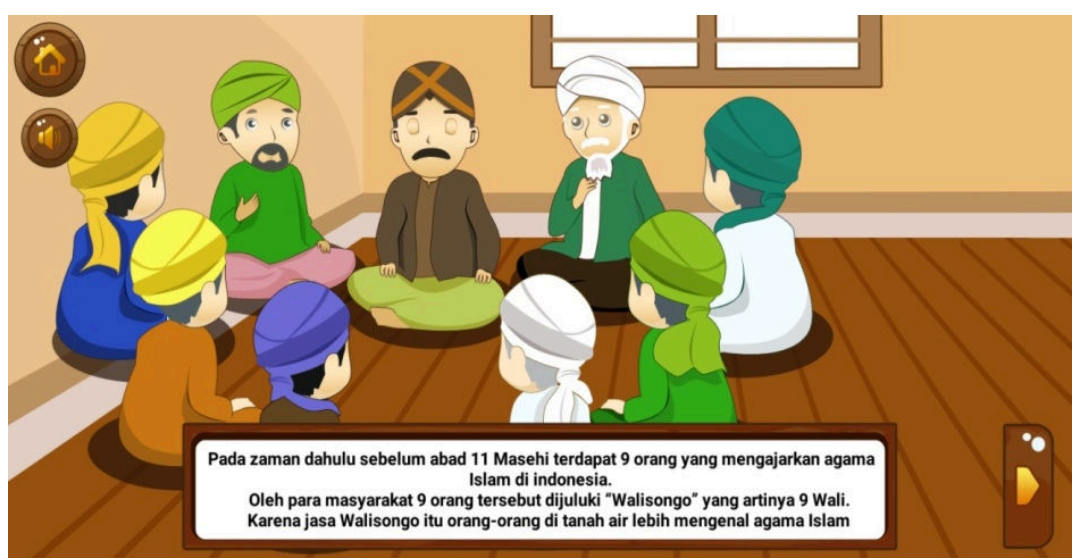

Fig. 3. Illustration of Walisongo's Story in the NU Kids Application

Through an interesting display of the infographics, it is easy for children to get to know the Walisongo characters and the locations of their da'wa distribution areas. The history encyclopedia menu displays not only Walisongo's da'wa journey but chronologically the children will study the history of Islam in Indonesia after the Walisongo period ended which was continued by scholars who came from several regions who later formed a religious organization known as Nahdlatul Ulama (NU). The introduction of the history of Nahdlatul Ulama as the successor to the preaching of Walisongo shows the message of the continuation of religious moderation which is continuously maintained by NU kyai. It is important for children to fully understand the history of the presence of Islam in Indonesia from the Walisongo era to the present, rooted in the values of moderate, tolerant and polite religious teachings. (Dwijayanto, 2017).

On the content of encyclopedia in NU Kids through Walisongo story not only displaying Islamic culture but also local culture. The story of Walisongo indicates a cultural blending between Islam and local culture through visualization of dress and the traditions used. When connected with what is happening today with the issue of transnational ideology, the two things are in contrast. Walisongo's da'wah strategy have succeeded in making peace or a middle way in addressing distance and cultural differences.

\subsection{Moderated Character Learning through Biography}

The making of moderate children's identities, especially in urban areas, is no longer through old religious authorities, from kiai or religious leaders, but through digital literary content. Through the NU Kids application, the biographical series of NU scholars, children have the space to learn about the life experience of a character and his contribution to the state. Through biographies moderated character learning become one of the making a moderate children's identity.

In the NU Kids application, children can also get to know brief biographies of Nahdlatul Ulama figures including KH Kholil Bangkalan, KH Hasyim Asyari Jombang, H. Hasan Gipo Surabaya, KH Ridwan Abdullah Surabaya, KH Bisri Syamsuri Jombang, KH Wahab Hasbullah, and another Nahdlatul Ulama figures. By getting to know Nahdlatul Ulama figures, children can not only know the founder, emblem creator and NU fighters during the independence era but can also further strengthen their love for Islamic warrior figures and at the same time love for the country. Biographical content can inspire children to imitate the 
characters of Nahdlatul Ulama figures. Modeling is the foundation for religious moderation as practiced by the founders of NU from its inception until now. Through biographical content, the internatization of children's moderation characters can be inspired by the founding figures of Nahdlatul Ulama.

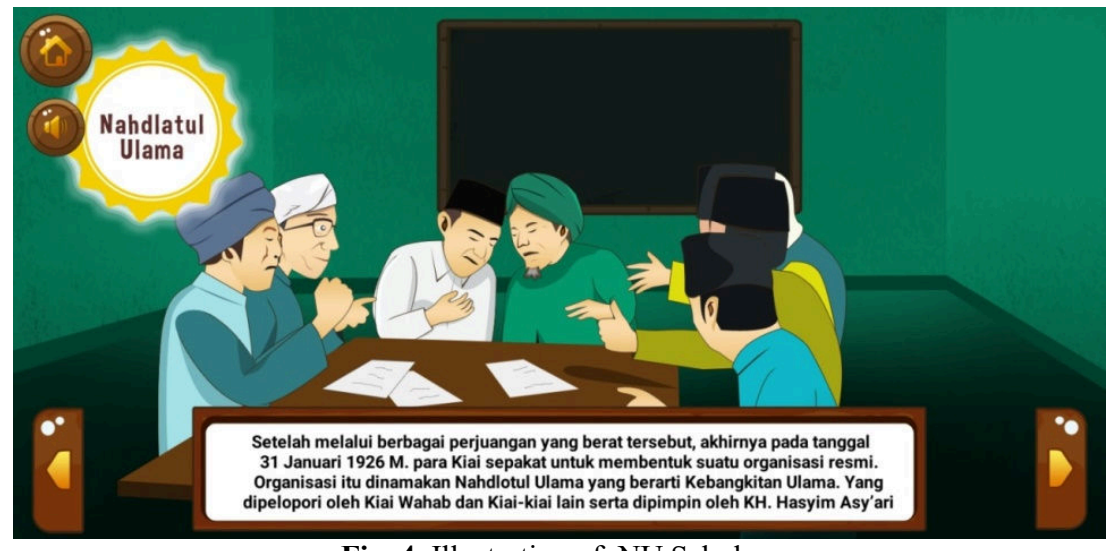

Fig. 4. Illustration of NU Scholars

\subsection{Religious Moderation Learning through NU Traditions}

In addition to getting to know NU characters, through the NU Kids application, children can learn about the religious practices that are carried out and preserved by Nahdlatul Ulama. Among them are Yasinan and Tahlilan to pray for people who have died, Istighotsah to ask Allah for help, Maulidan for the anniversary of the birth of the Prophet Muhammad and other traditions. By understanding the traditions and practices of NU, the cultivation of moderate religious values of children will be formed so that it will not be easy to blame local culture which has been covered with religious teachings. The religious identity of the child will be moderately strengthened by the preservation of the Nahdlatul Ulama religious practices.

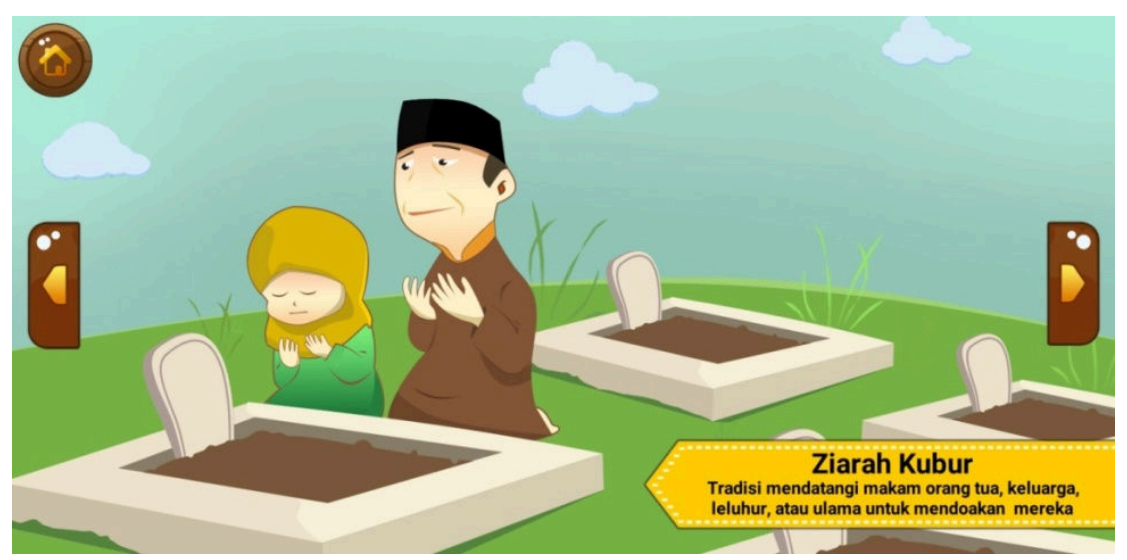

Fig. 5. Illustration of Grave Pilgrimage Traditions in the NU Kids Application 


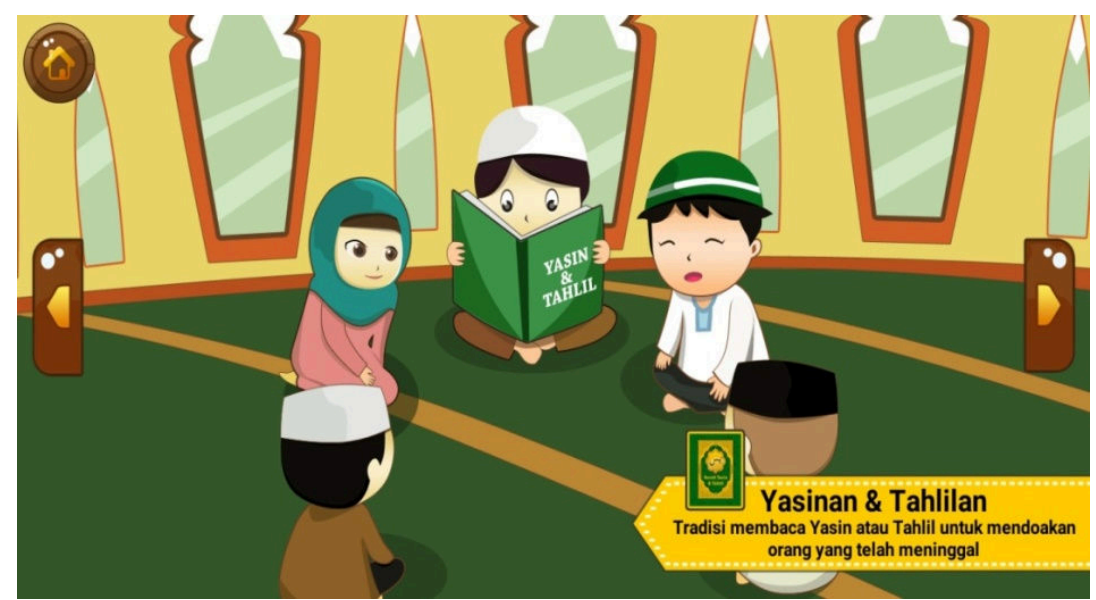

Fig. 6. Illustration of Yasinan and Tahlilan in the NU Kids Application

\subsection{Strengthening Religious Moderation through Games and Songs}

In the NU Kids application, there is a Mini Games menu, there are several educational games that have insight into the values of religious moderation, including the quiz to guess the names of NU figures, the quiz to guess the location of the Walisongo's graves and games related to the treasures of madrassas and Islamic boarding schools. Through quizzes, children learn to understand the values of moderation as the pillars of the Nahdlatul Ulama. Educating the values of religious moderation through games in the NU Kids application can indirectly form children with moderate insights. Besides through games (mini games), the NU Kids application also presents Mars songs that can spark the spirit of children's nationalism. Among them is the mars syubbanul wathon which has been popular among madrassas, Islamic boarding schools and the Nahdlatul Ulama community. The lyrics of Mars syubbanul wathon written by KH Wahab Hasbullah have a strong national message so that children are patriotic in defending their homeland. Thus Islamic digital literature such as the NU Kids application can be a source of alternative religious knowledge and a medium for making the moderate identity of children in Indonesia so that they are not exposed to intolerant and even radical religious understandings.

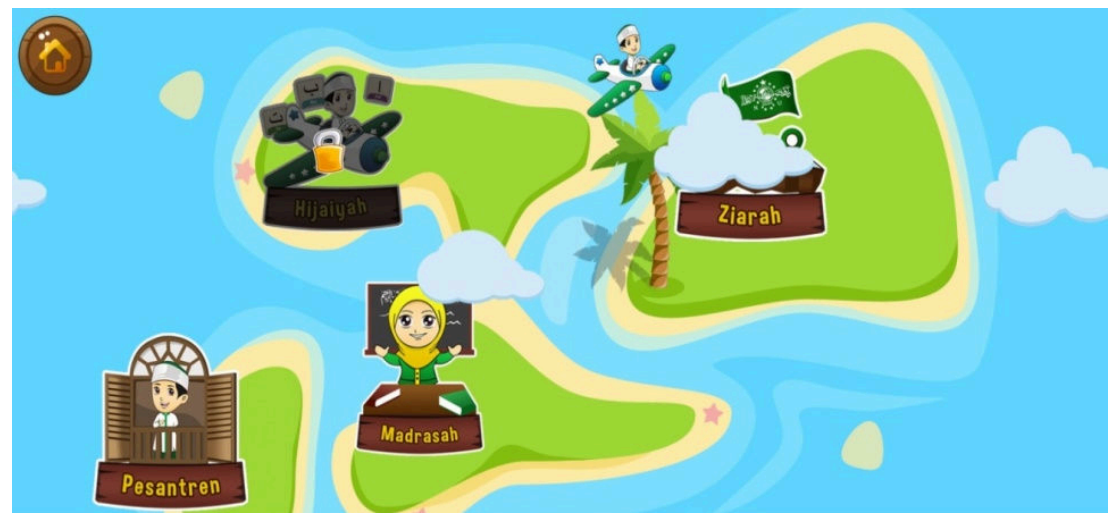

Fig. 7. Display of Mini Games in the NU Kids Application 
Therefore NU kids as Islamic digital literature displays learning fun in many ways. Visual content make children have an imagination of the values they learn. Not only that they were also treated to "learn by playing". This can be seen in the presence of mini games and song content in NU Kids application.

\section{Conclusion}

The presence of religious digital literature such as the NU Kids application is a source of representation for the formation of a moderate religious identity for children. The NU Kids application has educational content that is based on the values of religious moderation for children in the digital era. Among them are encyclopedia content that presents a moderating understanding of the history of the arrival of Islam in Indonesia through the intermediaries of the Walisongo who spread Islam in a peaceful way without violence. In the content, the characters also provide inspiration for children to emulate the founders and fighters of NU from the era of independence to today's era. Modeling is the foundation for religious moderation as practiced by the founders of NU.

In cultural content with an attractive visual appearance, children are also introduced to learning the diversity of local traditions such as the slametan tradition, grave pilgrimage, mauludan, wayangan and others. By getting to know the religious traditions of the community, children have moderate thoughts and attitudes in appreciating the wisdom of the local culture in their environment. Not only education in the form of an encyclopedia, the NU Kids application also presents games with insight into religious moderation values through quizzes to guess the names of NU figures, quiz to guess the location of the Walisongo's graves and other games. Thus, the NU Kids application can be an alternative and source for the making of moderate children's religious identities in Indonesia.

\section{References}

[1] Allan, C. Playing with Picturebooks: Postmodernism and the Postmodernesque. New York: Palgrave Macmillan, (2012).

[2] Azak, U. The New Happy Child in Islamic Picture Books. In C. J. Gruber \& S. H. Turkey (Eds.), Visual Culture in Te Modern Middle East. Bloomington, Indiana, United States: Indiana University Press, (2013).

[3] Budiyanto, A. (Playing with Piety: The Phenomenon of Indonesian Muslim Dolls. Journal of South Asian Studies, 9, 3-14, (2009).

[4] Dwijayanto, A. Pribumisasi Islam Nusantara: Antara Nalar Beragama dan Gerakan Sosial Keagamaan di Indonesia. Vol. 9 No.2, pp 71-92, QALAMUNA: Jurnal Pendidikan, Sosial, dan Agama, (2017).

[5] Peran Barisan Ansor Serbaguna (Banser) dalam Menangkal Radikalisme. Vol.16 No.2, pp 127-146, Farabi, (2019).

[6] Emmison, M., Smith, P., \& Mayall ,M. Researching The Visual (2nd Ed). Singapore: SAGE Publications Asia-Pacific Pte Ltd, (2012).

[7] Lyansari, KA,: Belajar Islam Melalui Literatur Visual: Pemebentukan Identitas Moderat Anak Muslim Milenial, Vol. 4 No.2, pp.293-316, Al-Balagh: Jurnal Dakwah dan Komunikasi, (2019). 
[8] Meneley, A. Fashions and Fundamentalisms in Fin-de-Siecle Yemen: Chador Barbie and Islamic Socks. Cultural Anthropology, 22(2), 214-244. https://doi.org/10.1525/can.2007.22.2.214, (2007).

[9] Morgan, D. The Sacred Gaze: Religious Visual Culture in Theory and Practice. Berkeley, California, United States: University of California Press, (2005).

[10] Pusat Pengkajian Islam dan Masyarakat. 2017. Survey PPIM: Internet, Pemerintah, dan Pembentukan Sikap Keberagamaan Generasi Z. https://ppim.uinjkt.ac.id/id/survey-ppim-internet-pemerintahdan-pembentukan-sikapkeberagamaangenerasi-z. accesed on July, 29 (2020).

[11] Stephens, J. Introduction: The Politics of Identity: A Transcultural Perspective on Subjectivity in Writing for Children. In J. Stephens (Ed.), Subjectivity in Asian Children's Literature and Film: Global Theories and Implications pp. 1-18. London, United Kingdom: Routledge, (2013).

[12] Willams, R. R. Why Study Religion Visually. In R. R. Williams (Ed.), Seeing Religion Toward a Visual Sociology of Religion. London, United Kingdom: Routledge, (2015). 